\title{
Formation of Bivalent Metal Complexes of Quaternary Pyridine and Poly(4-vinylpyridine) Containing Uracil ${ }^{\dagger}$
}

\author{
Akio Kurose, Yasuhiro Hayashi, ${ }^{*}$ Toshiki Koyama, ${ }^{*}$ \\ Kenji Hanabusa, ${ }^{*}$ Hirofusa ShIRAI, ${ }^{*}$ \\ and Kiichi TAKEMOTO** \\ Konan Women's Junior College, Konan 483, Japan \\ * Department of Functional Polymer Science, Faculty of Textile Science \\ and Technology, Shinshu University, \\ Ueda 386, Japan \\ ** Department of Applied Fine Chemistry, Faculty of Engineering, \\ Osaka University, Suita 565, Japan
}

(Received August 9, 1989)

\begin{abstract}
Monomeric and polymeric compounds containing uracil group, i.e., 3-[2,4(3H)pyrimidinedionyl]propylpyridinium bromide (2) and quaternary poly(4-vinylpyridine) containing 2,4(3H)-pyrimidinedione (4), were prepared and their complexation with bivalent metal ions was studied by visible and ESR spectroscopy. The concentrated methanolic solution of monomeric ligand 2 and bivalent metal ions like copper(II), cobalt(II), and zinc(II) gave mixed ligand complexes $(5 \mathbf{a}-\mathbf{c})$ consisting of two molecules of $\mathbf{2}$, two molecules of methanol, and one bivalent metal ion. Complexes $\mathbf{5 a}-\mathbf{c}$ in dilute methanolic solution were unstable and transformed to complexes 6 consisting of four molecules of 2 and one ion of bivalent metal. The uracil group of polymer 4 in methanol did not give a mixed ligand complex like 5 but exclusively formed the complex of type 6. On the other hand, compounds $\mathbf{2}$ and $\mathbf{4}$ with tetraamminecopper(II) bromide in water gave mixed ligand complexes composed of two molecules of uracil residue, two molecules of ammonia, and one molecular copper(II) ion.
\end{abstract}

KEY WORDS Uracil / Poly(4-vinyl pyridine) / Bivalent Metal / Electron Spin Resonance /

The interactions of DNA with metal ions, especially bivalent metal ions, are interesting in connection with the functions of nucleic acids, such as DNA replication, transcription of genetic codes, and enzyme reactions with DNA. $^{2,3}$ In particular, the copper(II) ion has the strongest complexation ability with DNA. However, related experiments ${ }^{4-10}$ so far have been carried out at a molar ratio of total copper(II) ions $\left([\mathrm{Cu}(\mathrm{II})]_{\mathrm{t}}\right)$ to monomeric unit of DNA ([HL]), [Cu(II) $]_{\mathrm{t}} /[\mathrm{HL}]$, larger than 0.5 . Under such conditions, it is difficult to form a uniform coordination, because DNA offers two kinds of coordination sites to bivalent metal ions, that is, phosphoric acid residues and nucleobases. Our previous paper reports that copper(II) ions are coordinated mainly with the phosphoric acid residues of DNA at molar ratio of $[\mathrm{Cu}(\mathrm{II})]_{\mathrm{t}} /[\mathrm{HL}]$, less than $0.33 .{ }^{11}$ Thus, it is important to discuss each of the two coordination sites separately. On the other hand, with respect to complexes of uracil with bivalent metal ions, only a few well defined complexes have been isolated and characterized, ${ }^{12-14}$ though uracil in RNA can play an important role as a ligand through its different

This is part 11 in the series of "Metal Complex in Biopolymers and Their Biological Functions. Part XI. For Part $\mathrm{X}$, see ref 1 . 
donor atoms. ${ }^{12.15}$

The purpose of this paper is to synthesize uniform coordination complexes of polymer containing uracil with bivalent metal ions as well as its low molecular model complexes and to characterize them.

\section{EXPERIMENTAL}

\section{3-[2,4(3H)-Pyrimidinedionyl]propylpyridinium}

Bromide (2)

A solution of $10.0 \mathrm{~g}(0.043 \mathrm{~mol})$ of 1-(3bromopropyl-[2,4(3H)-pyrimidinedione ${ }^{16}$ (1), that is, 1-(3-bromopropyl)uracil in $100 \mathrm{ml}$ of pyridine was stirred at $80^{\circ} \mathrm{C}$ for $20 \mathrm{~h}$. Methanol was added to the residue after removing pyridine and further evaporated. This operation was repeated 5 times, and then dry ether was added to the resulting oil. The product solidified after one week was filtered off and recrystallized from methanol. Yield: $12.1 \mathrm{~g}$ $(90 \%)$. Anal. Calcd for $\mathrm{C}_{12} \mathrm{H}_{14} \mathrm{~N}_{3} \mathrm{O}_{2} \mathrm{Br}$ : C, $43.65 \% ; \mathrm{H}, 4.88 \%$; N, $12.73 \%$. Found: $\mathrm{C}$, $43.79 \%$; H, $4.98 \%$; N, $12.44 \%$.

${ }^{1} \mathrm{H}$ NMR (DMSO- $\left.d_{6}\right): 2.5\left(\mathrm{~m}, 2 \mathrm{H},-\mathrm{CH}_{2}-\right.$ $\left.\mathrm{CH}_{2} \mathrm{CH}_{2}-\right), 3.9$ (t, $\left.2 \mathrm{H},-\mathrm{CH}_{2} \mathrm{CH}_{2} \mathrm{CH}_{2}-\mathrm{N}_{-}^{-}\right)$, $4.7\left(\mathrm{t}, 2 \mathrm{H}, 2 \mathrm{~N}^{+}-\mathrm{CH}_{2} \mathrm{CH}_{2} \mathrm{CH}_{2}-\right), 5.7(\mathrm{~d}, 1 \mathrm{H}$, proton of 5-position in pyrimidinedionyl), $7.7 \mathrm{~d}, 1 \mathrm{H}$, proton of 6-position in pyrimidinedionyl), 8.1-9.0 (m, 5H, aromatic protons in pyridinium), and 11.2 (br, $1 \mathrm{~h}$, proton of 3position in pyrimidinedionyl). IR $(\mathrm{KBr})$ : $3400\left(v_{\mathrm{NH}}\right), 3020\left(v_{\mathrm{CH}}\right), 1660\left(v_{\mathrm{C}=\mathrm{o}}\right)$, and 1620 $\mathrm{cm}^{-1}\left(v_{\mathrm{C}=0}\right)$. UV (water): $\lambda_{\max }(\varepsilon)=260 \mathrm{~nm}$ (12300).

\section{Poly(4-vinylpyridine) Containing 2,4(3H)-Py- rimidinedione (3)}

A solution of $50 \mathrm{~g}$ of freshly distilled 4vinylpyridine and $50 \mathrm{mg}$ of AIBN in $150 \mathrm{ml}$ of distilled methanol was heated to $70^{\circ} \mathrm{C}$ for $30 \mathrm{~h}$ under a nitrogen atmosphere. The resulting viscous solution was poured into $1000 \mathrm{ml}$ of stirred petroleum ether and the precipitate was collected. The polymer was redissolved in $200 \mathrm{ml}$ of ethanol and precipitated by addition to $1000 \mathrm{ml}$ of petroleum ether. After drying, a yield of $43 \mathrm{~g}$ of poly(4-vinylpyridine) having a 221000 viscosity-average molecular weight $^{17}$ (DP $=2100)$ was obtained.

A solution of $5.26 \mathrm{~g}(0.05$ unit-mol $)$ of poly(4-vinylpyridine) and $11.65 \mathrm{~g}(0.05 \mathrm{~mol})$ of 1 in $50 \mathrm{ml}$ of distilled DMF was stirred at room temperature for $24 \mathrm{~h}$, and then the contents were added to $500 \mathrm{ml}$ of dioxane. The collected and dried polymer was redissolved in $30 \mathrm{ml}$ of a water-DMF mixture (1:5 vol ratio) and precipitated by addition to $500 \mathrm{ml}$ of dioxane. A yield of $5.52 \mathrm{~g}$ of poly(4-vinylpyridine) containing 30.0 unit-mol\% of uracil (3) was obtained. Anal. Calcd for $\left(\mathrm{C}_{14} \mathrm{H}_{16} \mathrm{~N}_{3} \mathrm{O}_{2} \mathrm{Br}\right)_{0.3}\left(\mathrm{C}_{7}\right.$ $\left.\mathrm{H}_{7} \mathrm{~N}\right)_{0.7}: \mathrm{C}, 62.44 \%$; H, $5.59 \%$; N, $12.80 \%$; Br, $13.69 \%$. Found: $\mathrm{C}, 63.67 \% ; \mathrm{H}, 5.41 \% ; \mathrm{N}$, $12.99 \%$; Br, $13.68 \%$. IR (KBr): $3400\left(v_{\mathrm{NH}}\right)$, and $1650 \mathrm{~cm}^{-1}\left(v_{\mathrm{C}=0}\right)$. UV (water): $\lambda_{\max }=260 \mathrm{~nm}$.

\section{Quarternary Poly(4-vinylpyridine) Containing} 2,4(3H)-Pyrimidinedione (4)

A solution of $5.0 \mathrm{~g}$ of polymer 3 and $10 \mathrm{ml}$ bromoethane in $50 \mathrm{ml}$ of distilled methanol was stirred at $40^{\circ} \mathrm{C}$ for $60 \mathrm{~h}$. The solution was added to $500 \mathrm{ml}$ of dioxane to afford a precipitate. The precipitate was dissolved in water and poured into $500 \mathrm{ml}$ of acetone. After this procedure was repeated twice, the polymer was collected on a glass filter funnel and dried. A yield of $4.57 \mathrm{~g}$ of poly(4-vinylpyridine) containing uracil (4) quarternized by bromoethane was obtained. Anal. Calcd for $\left(\mathrm{C}_{14} \mathrm{H}_{16} \mathrm{~N}_{3} \mathrm{O}_{3}\right.$ $\mathrm{Br})_{0.30}\left(\mathrm{C}_{9} \mathrm{H}_{12} \mathrm{NBr}\right)_{0.65}\left(\mathrm{C}_{7} \mathrm{H}_{7} \mathrm{~N}\right)_{0.05}: \mathrm{C}, 50.80 \%$; $\mathrm{H}, 5.31 \%$; H, 9.14\%; $\mathrm{Br}, 30.87 \%$. Found: $\mathrm{C}$, $48.90 \%$; H, $5.23 \%$; N, $8.71 \%$; Br, 30.84\%. IR $(\mathrm{KBr}): 3400\left(v_{\mathrm{NH}}\right), 1650\left(v_{\mathrm{C}=\mathrm{o}}\right)$, and $1430 \mathrm{~cm}^{-1}$ $\left(\delta_{\mathrm{CH}}\right)$. UV (water): $\lambda_{\max }=260 \mathrm{~nm}$.

\section{Bis[3-(12,4-pyrimidinedionyl )propylpyridinium} Bromide]Dimethanolcopper(II) (5a)

A solution of $1.0 \mathrm{~g}(3.2 \mathrm{mmol})$ of 2 in $4 \mathrm{ml}$ of methanol was added to $0.358 \mathrm{~g}(1.6 \mathrm{mmol})$ of copper(II) bromide in $1 \mathrm{ml}$ of methanol. The obtained dark green precipitate was filtered off and washed with cold methanol. A yield of 
$0.65 \mathrm{~g}\left(54^{\%}\right)$ of copper(II) complex (5a) was obtained after four recrystallization from methanol. Anal. Calcd for $\mathrm{C}_{26} \mathrm{H}_{34} \mathrm{~N}_{6} \mathrm{O}_{6} \mathrm{Br}_{2} \mathrm{Cu}$ : $\mathrm{C}, 41.64 \%$; H, $4.57 \%$; N $11.21 \%$; Br, $21.31 \%$; $\mathrm{Cu}, 8.47 \%$. Found: $\mathrm{C}, 42.00 \% ; \mathrm{H}, 4.32 \%$; $\mathrm{N}, 10.89 \%$; Br, $21.19 \%$; Cu, $8.45 \%$. IR (KBr): 1690, 1660, $1630 \mathrm{~cm}^{-1}\left(v_{\mathrm{C}=\mathrm{o}}\right)$, and $390 \mathrm{~cm}^{-1}$ $\left(v_{\mathrm{N}-\mathrm{Cu}}\right)$. VIS (Reflection): $\quad \lambda_{\max }=360,540$, $580 \mathrm{~nm}$. mp: $168^{\circ} \mathrm{C}$ (dec.).

Bis[3-(2,4-pyrimidinedionyl)propylpyridinium Bromide]Dimethanolcobalt(II) (5b)

The bright blue cobalt(II) complex 5b was obtained in a $42 \%$ yield by the same procedure described for 5a. Anal. Calcd for $\mathrm{C}_{26} \mathrm{H}_{34} \mathrm{~N}_{6} \mathrm{O}_{6} \mathrm{Br}_{2} \mathrm{Co}: \mathrm{C}, 41.90 \% ; \mathrm{H}, 4.60 \% ; \mathrm{N}$, $11.28 \%$; Br, $21.44 \%$; Co, $7.91 \%$. Found: C, $42.25 \%$; H, $4.61 \%$; N, $11.57 \%$; Br, $21.45 \%$; Co, $7.86 \%$. IR (KBr): 1690, 1660, $1630 \mathrm{~cm}^{-1}$ $\left(v_{\mathrm{C}=\mathrm{o}}\right)$, and $390 \mathrm{~cm}^{-1}\left(v_{\mathrm{N}-\mathrm{Co}}\right)$. VIS (Reflection): $\lambda_{\max }=640,675,705 \mathrm{~nm}$. mp: $214^{\circ} \mathrm{C}$ (dec.).

\section{Bis[3-(2,4-pyrimidinedionyl )propylpyridinium} Bromide]Dimethanolzinc (II) (5c)

The colorless zinc(II) complex 5c was obtained in a $34 \%$ yield by the same procedure as described above. Anal. Calcd for $\mathrm{C}_{26} \mathrm{H}_{34^{-}}$ $\mathrm{N}_{6} \mathrm{O}_{6} \mathrm{Br}_{2} \mathrm{Zn}: \mathrm{C}, 41.54 \%$; H, $4.56 \%$; N, $11.18 \%$; $\mathrm{Br}, 21.16 \%$; $\mathrm{Zn}, 8.70 \%$. Found: C, $41.19 \%$; $\mathrm{H}, 4.12 \%$; N, $10.89 \%$; Br, $21.03 \%$; $\mathrm{Zn}, 8.64 \%$. IR (KBr): 1690, 1660, $1630 \mathrm{~cm}^{-1}\left(v_{\mathrm{C}=\mathrm{O}}\right)$, and $350 \mathrm{~cm}^{-1}\left(v_{\mathrm{N}-\mathrm{Zn}}\right) \cdot \mathrm{mp}: 257^{\circ} \mathrm{C}(\mathrm{dec}$.$) .$

${ }^{1} \mathrm{H}$ NMR (DMSO- $\left.d_{6}\right): 2.5 \quad(\mathrm{~m}, \quad 4 \mathrm{H}$, $\left.-\mathrm{CH}_{2} \mathrm{CH}_{2} \mathrm{CH}_{2}-\right), 3.4$ (s, $\left.6 \mathrm{H}, \mathrm{CH}_{3} \mathrm{OH}\right), 3.9$ (t, $\left.4 \mathrm{H},-\mathrm{CH}_{2} \mathrm{CH}_{2} \mathrm{CH}_{2}-\mathrm{N}^{-}\right), 4.7\left(\mathrm{t}, 4 \mathrm{H}, 2 \mathrm{~N}^{+}-\right.$ $\mathrm{CH}_{2} \mathrm{CH}_{2} \mathrm{CH}_{2}-$ ), 5.7 (d, $2 \mathrm{H}$, proton of 5-position in pyrimidinedionyl), $7.7(\mathrm{~d}, 2 \mathrm{H}$, proton of 6-position in pyrimidinedionyl), and 8.1$9.0(\mathrm{~m}, 10 \mathrm{H}$, aromatic protons in pyridinium).

Copper(II) Complex of Quarternary Poly(4vinylpyridine) Containing Uracil (7)

To a solution of $1.0 \mathrm{~g}(1.22 \mathrm{mmol}$ on the basis of uracil residue) of 4 in $10 \mathrm{ml}$ of methanol was gradually added a solution of 136 $\mathrm{mg}(0.61 \mathrm{mmol})$ of copper(II) bromide in $1 \mathrm{ml}$ of methanol. The solution changed from colorless to yellowish brown and then, an insoluble material was precipitated, filtered off and dried. Yield: $0.91 \mathrm{~g}$, VIS (methanol): $\lambda_{\max }=390,890 \mathrm{~nm}$.

Aqueous Solution of Copper(II) Complex of $\mathbf{2}$ A solution of $0.233 \mathrm{~g}(0.8 \mathrm{mmol})$ of tetraamminecopper(II) bromide in $1 \mathrm{ml}$ of water was added to a solution of $0.5 \mathrm{~g}(1.6 \mathrm{mmol})$ of 2 in $2 \mathrm{ml}$ of water. The mixture was stirred at room temperature for $2 \mathrm{~h}$, and then used for ESR spectroscopy.

\section{Aqueous Solution of Copper(II) Complex of 4}

A solution of $89 \mathrm{mg}(0.31 \mathrm{mmol})$ of tetraamminecopper(II) bromide in $1 \mathrm{ml}$ of water was added to a solution of $0.5 \mathrm{~g}(0.61 \mathrm{mmol}$ on the basis of uracil residue) of 4 in $4 \mathrm{ml}$ of water. The mixture was stirred at room temperature for $2 \mathrm{~h}$, and then used as such for ESR spectroscopy.

\section{RESULTS AND DISCUSSION}

Synthesis of 3-[2,4(3H)-Pyrimidinedionyl]propylpyridinium Bromide (2) and Quaternary Poly(4-vinylpyridine) Containing 2,4(3H)Pyrimidinedione (4)

Quarternary poly(4-vinylpyridine) containing uracil (4) and its low molecular model compound (2) were synthesized according to Scheme 1. Poly(4-vinylpyridine) $(\mathrm{DP}=2100)$ was quaternized by 1 -bromo-3-[2,4(3H)pyrimidinedionyl]propane (1) followed by bromoethane. The composition in the three units of the resulting quaternary polymer (4) was determined as described in Scheme 1 by $\mathrm{Br}$ elemental analysis.

Synthesis and Properties of Bis[3-(2,4-pyrimidinedinedionyl)propylpyridinium bromide]dimethanol $\mathrm{Mt}(\mathrm{II})(\mathbf{5 a}-\mathbf{c})$

A dark green precipitate was separated immediately after mixing two concentrated 
<smiles>O=c1ccn(CCCBr)c(=O)[nH]1</smiles>

1<smiles>O=c1ccn(CCC[n+]2ccccc2)c(=O)[nH]1</smiles>

2<smiles>[Y][Y]C(CCCCC)CCC(CC)c1cc[n+](CCCn2ccc(=O)[nH]c2=O)cc1</smiles>

3

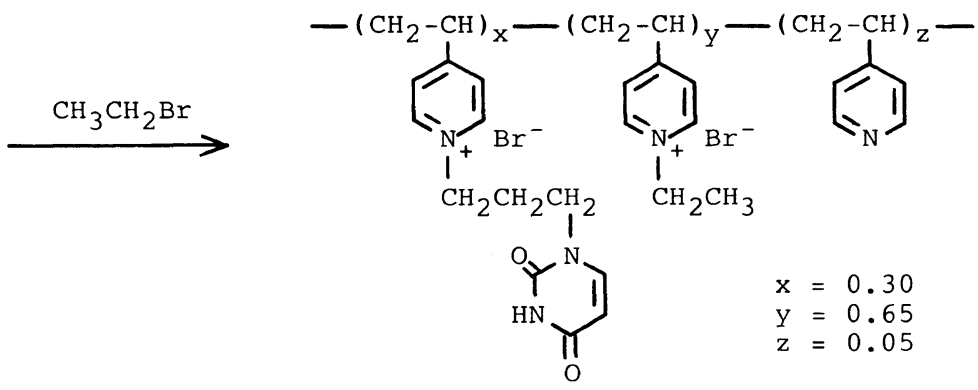

4

Scheme 1.

methanolic solutions of 2 and copper(II) bromide. The reflection spectrum of the precipitate is shown in Figure 1. The observed broad absorption at $545-620 \mathrm{~nm}$ is comparable to that of a d-d band owing to a $\mathrm{Cu}(\mathrm{II})-\mathrm{N}_{2}$ type complex. ${ }^{18}{ }^{1} \mathrm{H}$ NMR spectroscopy of the zinc(II) complex prepared by the same procedure confirmed the presence of two molecules of coordinate methanol. From elemental analysis, it may be concluded that the formed compounds are mixed ligand complexes $(\mathbf{5 a}-\mathbf{c})$ consisting of two molecules of $\mathbf{2}$, two molecules of methanol, and one ion of bivalent metal as shown in Scheme 2. Mixed ligand complexes of this type were obtained from copper(II), cobalt(II), and zinc(II) bromide, but not nickel(II) salt. Furthermore, a mixed ligand complex like 5a-c was not isolated by reaction in water or DMF. Analytical data of $\mathbf{5 a}-\mathbf{c}$ are summarized in 
Table I.

The VIS spectrum of dilute methanolic solution $\left(5.0 \times 10^{-3} \mathbf{M}\right)$ of complex $\mathbf{5 a}$ is characterized by broad maxima at 390 and $850 \mathrm{~nm}$, which are distinct from that of the reflection spectrum of 5a. The disappearance of absorption at $545-620 \mathrm{~nm}$ characteristic of d-d band of $\mathrm{Cu}(\mathrm{II})-\mathrm{N}_{2}$ complex in the reflection

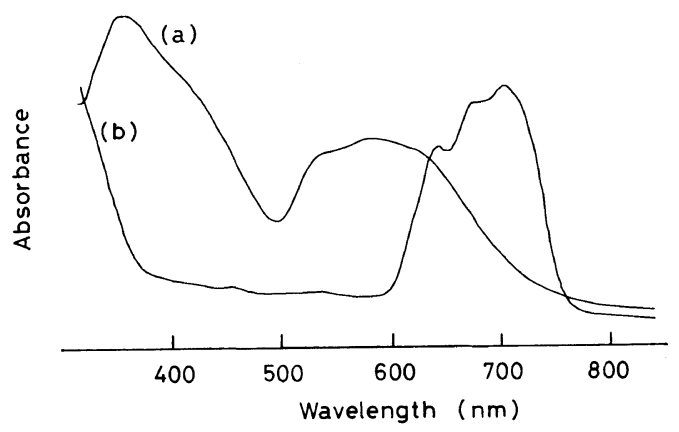

Figure 1. Reflection visible spectra of complex 5a (a) and $\mathbf{5 b}(\mathrm{b})$. spectrum suggests that the complex 5a was decomposed in the dilute methanolic solution. ESR spectra of the methanolic solution of

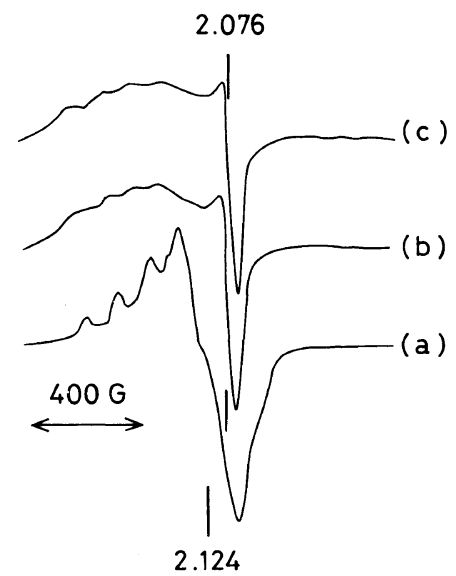

Figure 2. ESR spectra of copper(II) complexes in methanol. (a), methanolic solution of copper(II) bromide at $-150 \mathrm{C}$; (b), dilute methanolic solution of complex 5a at $-150^{\circ} \mathrm{C}$; (c), methanolic solution of polymer complex 7 at $-150^{\circ} \mathrm{C}$.

Table I. Analytical data for complexes 5a-c

\begin{tabular}{|c|c|c|c|c|c|c|}
\hline \multirow{2}{*}{ Comples } & \multirow{2}{*}{$\frac{\text { Yield }}{\%}$} & \multirow{2}{*}{$\frac{\text { Visible spectra }^{a}}{n m}$} & \multicolumn{2}{|c|}{ IR spectra $/ \mathrm{cm}^{-1}$} & \multicolumn{2}{|c|}{ Elemental anaysis ${ }^{b}$} \\
\hline & & & $v_{\mathrm{C}=\mathrm{o}}$ & $v_{\mathrm{NM}}$ & $\mathrm{Mt}$ & $\mathrm{Br}$ \\
\hline $5 a$ & 53 & $540-620(\mathrm{br})$ & $1630-1690$ & 390 & $8.45(8.47)$ & $21.19(21.34)$ \\
\hline $\mathbf{5 b}$ & 42 & $640,675,705$ & $1630-1690$ & 390 & $7.86(7.91)$ & $21.45(21.44)$ \\
\hline $5 c$ & 34 & - & $1630-1685$ & 390 & $8.64(8.70)$ & $21.03(21.26)$ \\
\hline
\end{tabular}

a Reflection spectra by $\mathrm{KBr}$ disk.

b Values in parentheses are theoritical.

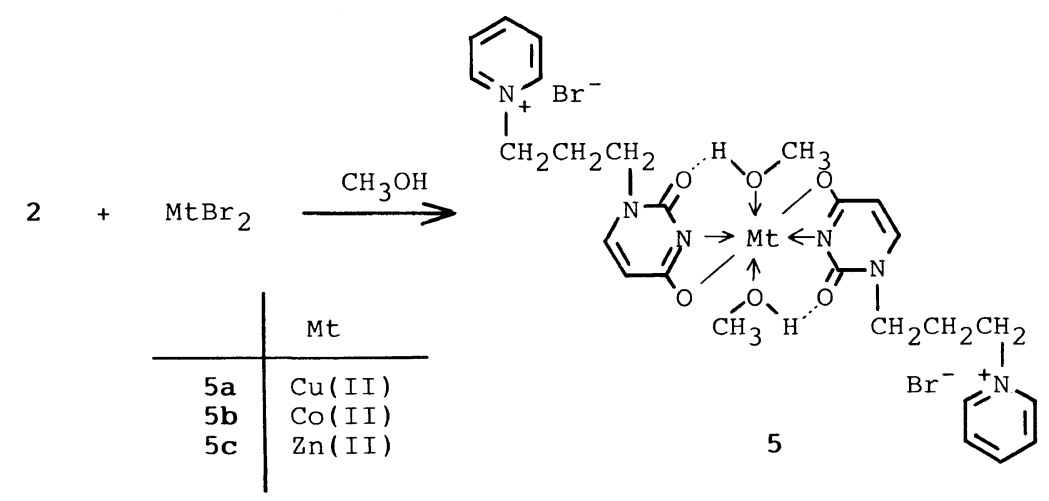

Scheme 2. 
copper(II) bromide and methanolic solution of 5a are illustrated in Figure 2. The $g$ value and signal pattern of spectra differ for the methanolic solutions of copper(II) bromide (a) and complex 5a (b). These results indicate that complex 5a transforms to another complex (6a), but not copper(II) bromide. Since the yellowish brown complex 6a could not be isolated, the molar ratio method was carried out on a mixture of compound $\mathbf{2}$ and copper(II) bromide to obtain information on this complex formed in a dilute methanolic solution of 5a. The plots of absorbance at $800 \mathrm{~nm}$ vs. $\left[\mathrm{CuBr}_{2}\right] /[2]$ when $[2]=0.02 \mathrm{M}$ are shown in Figure 3. The broken line having a point of intersection at a molar ratio $\left[\mathrm{CuBr}_{2}\right]$ $[2]=0.25$ was obtained. At this ratio, the formation of complex $\mathbf{6 a}$ may be completed. The increase in absorption over the ratio 0.25 may be ascribed to the increasing free copper(II) bromide which possesses an absorption band around $800 \mathrm{~nm}$. The point of intersection at $\left[\mathrm{CuBr}_{2}\right] /[2]=0.25$ suggests that complex $\mathbf{6 a}$ consists of four molecules of 2 and one ion of copper(II). From the results mentioned above, it can be concluded that bivalent metal complexes $\mathbf{6}$ consisting of four molecules of $\mathbf{2}$ and one ion of $\mathrm{Mt}(\mathrm{II})$ are formed from compound 2 and $\mathrm{Mt}(\mathrm{II})$ bromide in dilute solution, and the mixed ligand bivalent metal complexes $\mathbf{5}$ are separated when concentrating.

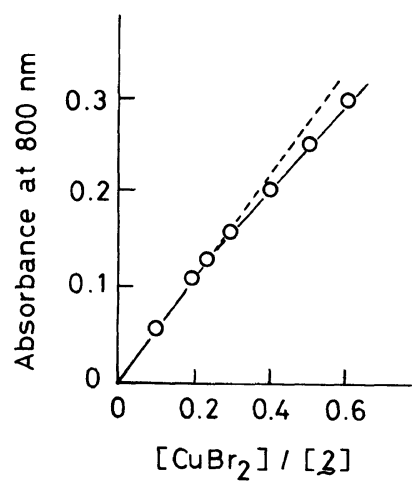

Figure 3. Plots of absorbance at $800 \mathrm{~nm}$ versus $\left[\mathrm{CuBr}_{2} \mathrm{y} / 2\right] .[2]=0.02 \mathrm{M}$.
Synthesis and Properties of Copper(II) Complex

(7) of Quaternary Poly(4-vinylpyridine) Containing Uracil

A methanolic solution of 4 changes from colorless to yellow by adding copper(II) bromide and gradually a yellowish brown matter (7) is precipitated. The precipitate 7 resembles complex 6a very closely in VIS spectroscopy, i.e., it is characterized by broad maxima at 390 and $850 \mathrm{~nm}$. The $g$ value and signal pattern of ESR spectrum of 7 are also the same as those of $6 a$ (Figure 2c). It thus seems that a quaternary polymer containing uracil $\mathbf{4}$ forms polymer complex 7 which is structurally similar to 6 a consisting of four molecules of uracil and one molecular ion of copper(II). However, a mixed ligand complex like 5 composed of two molecules of uracil, two molecules of methanol, and one ion of $\mathrm{Mt}$ (II) was not obtained from polymer 4 , in contrast with low molecular ligand 2. Formation of the mixed ligand complex from polymer 4 and bivalent metal ion in methanol is presumably hindered by the inhibitory effect of ethylpyridinium cation in the vicinity of uracil residues.

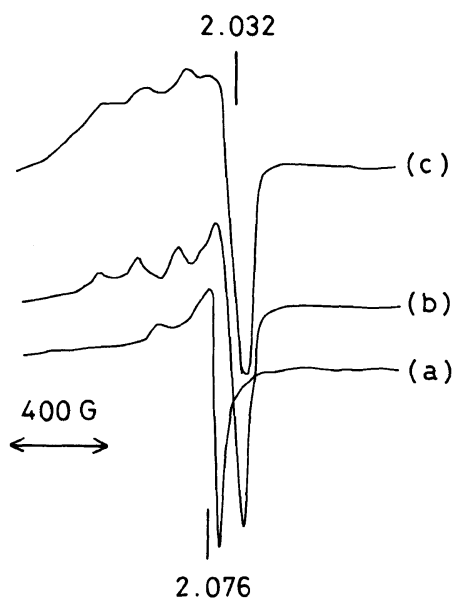

Figure 4. ESR spectra of copper(II) complexes in water. (a), aqueous solution of tetraamminecopper(II) bromide at $-150 \mathrm{C}$; (b), aqueous solution containing tetraamminecopper(II) bromide and 2 at $-150 \mathrm{C}$; (c), aqueous solution containing tetraamminecopper(II) bromide and 4 at $-150 \mathrm{C}$. 


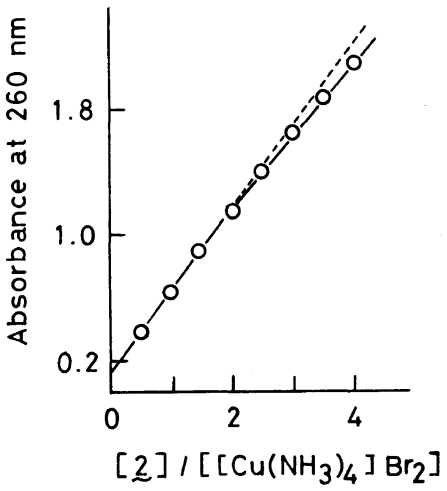

Figure 5. Plots of absorbance at $260 \mathrm{~nm}$ versus [2V $\left[\left[\mathrm{Cu}\left(\mathrm{NH}_{3}\right)_{4}\right] \mathrm{Br}_{2}\right]$. [[Cu( $\left.\left.\left.\mathrm{NH}_{3}\right)_{4}\right] \mathrm{Br}_{2}\right]=0.01 \mathrm{M}$.

\section{Formation of Mixed Ligand Copper(II) Complexes in Aqueous Solution \\ Formation of copper(II) complexes from} copper(II) bromide and $\mathbf{2}$ or $\mathbf{4}$, was attempted in water. However, these aqueous solutions gave ESR spectra similar to that of copper(II) bromide without $\mathbf{2}$ or $\mathbf{4}$ and it is thus considered that neither $\mathbf{2}$ nor $\mathbf{4}$ produce any significant copper(II) complexes in these aqueous solutions. On the other hand, ESR spectra of aqueous solution containing 2 and tetraamminecopper(II) bromide gave a $g$ value and signal pattern different from tetraamminecopper(II) bromide in water (Figures 4a and b), which suggests the formation of a particular copper(II) complex. The results of the molar ratio method from a mixture of 2 and tetraamminecopper(II) bromide in water are shown in Figure 5. The point of intersection at the molar ratio $[2] /\left[\mathrm{Cu}\left(\mathrm{NH}_{3}\right)_{4}\right] \mathrm{Br}_{2}=2$ also suggests the formation of a new mixed ligand copper(II) complex, which may be composed of two molecules of $\mathbf{2}$, two molecules of ammonia, and one copper(II) ion. ${ }^{19}$ The ESR spectrum of the mixture of 4 and tetraammine-
copper(II) bromide in water resembles closely that of 2 and tetraamminecopper(II) bromide (Figure 4). From these results, the presence of a second ligand like ammonia may perhaps be reasonably concluded essential for the coordination of uracil to copper(II) ion in polymer $\mathbf{4}$ and compound 2 .

\section{REFERENCES}

1. Y. Nakamura, H. Shirai, and N. Hojo, Kobunshi Ronbunshu, 45, 889 (1988).

2. G. L. Eichhorn, "Inorganic Biochemistry," Vol. 2, Elsevier, Amsterdam, 1973, p 1210.

3. H. Pezzano and F. Podo, Chem. Rev., 80, 366 (1980).

4. H. Richard, J. P. Schreiber, and M. Daune, Biopolymers, 12, 1 (1973).

5. J. M. Rifkind, Y. A. Shin, J. M. Heim, and G. L. Eichhorn, Biopolymers, 15, 1879 (1976).

6. P. M. Lausarot and R. P. Ferrai, Inorg. Chim. Acta, 33, 145 (1979).

7. V. G. Bregadze, E. S. Gelagutashvili, and M. G. Kharatishvili, Stud. Biophys., 67, 25 (1978).

8. W. A. Prutz, Radiat. Environ. Biophys., 23, 7 (1984).

9. H. Lang and Ch. Zimmer, Stud. Biophys., 102, 107 (1984).

10. M. Matzeu and G. Onori, Photochem. Photobiol., 44, 59 (1986)

11. H. Shirai, Y. Itoh, A. Kurose, K. Hanabusa, K. Abe, and N. Hojo, Polym. J., 16, 207 (1984).

12. M. Goodgame and K. W. Johns, J. Chem. Soc., Dalton, 1680 (1977).

13. A. R. Sarkar and P. Ghosh, Inorg. Chim. Acta, 78 , L39 (1983).

14. P. Ghosh, T. K. Mukhopadhyay, and A. R. Sarkar, Transition Met. Chem., 9, 46 (1984).

15. M. Goodgame and K. W. Johns, Inorg. Chim. Acta, 78, L335 (1978).

16. D. T. Browne, J. Eisinger, and N. J. Leonard, J. Am. Chem. Soc., 90, 7302 (1968).

17. K. Dialer and K. Vogler, Makromol. Chem., 6, 191 (1951).

18. R. J. Dudley, R. J. Fereday, B. J. Hathaway, P. G. Hodgson, and P. C. Powder, J. Chem. Soc., Dalton, 882 (1972)

19. I. Mutikainen, Ann. Acad. Sci. Fenn. Ser., A2, 217, 1 (1988). 